\title{
Effect of an Acid Diet Allied to Sonic Toothbrushing on Root Dentin Permeability: An In Vitro Study
}

\author{
Shelon Cristina Souza PINTO \\ Roberta Grasseli BATITUCCI \\ Michele Carolina PINHEIRO \\ Daniela Leal ZANDIM \\ Rubens SPIN-NETO \\ José Eduardo Cezar SAMPAIO
}

Department of Oral Diagnosis and Surgery, Araraquara Dental School, São Paulo State University, Araraquara, SP, Brazil

\begin{abstract}
This study quantified alterations in root dentin permeability after exposure to different acid beverages. Twenty-five third molars were sectioned below the cementoenamel junction, the root segment was collected, and the pulp tissue was removed. The root segments were connected to a hydraulic pressure apparatus to measure the permeability of root dentin after the following sequential steps, with 5 specimens in each: 1) phosphoric acid etching for $30 \mathrm{~s}$ (maximum permeability), 2) root planning to create new smear layer, 3 ) exposure to different acid substances for 5 min (orange, cola drink, vinegar, white wine, lemon juice), 4) toothbrushing with sonic toothbrush for $3 \mathrm{~min}, 5$ ) toothbrushing with sonic toothbrush plus dentifrice for $3 \mathrm{~min}$. Considering step I as $100 \%$, the data were converted into percentage and each specimen was its own control. Data were analyzed statistically by Kruskal-Wallis and Dunn's post test at 5\% significance level. All acidic substances increased dentin permeability significantly after scraping ( $<<0.05)$. Toothbrushing after exposure to acid substances decreased dentin permeability and the association with dentifrice accentuated the decrease ( $<<0.05$ ), except for the specimens treated with cola drink. Thus, it may be concluded that all tested acid fruit juices increased dentin permeability, and toothbrushing with or without dentifrice can decrease root dentin permeability after dentin exposure to acid diet.
\end{abstract}

Key Words: acidic beverages, dentin, toothbrushing.

\section{INTRODUCTION}

Life expectancy has increased and patients have retained their natural teeth for a longer time due to effective preventive and treatment strategies for caries and periodontal disease. Consequently, there is a higher risk of developing cervical dentin hypersensitivity, as a result of physiological gingival recession (1).

Dentin hypersensitivity may be defined as pain arising from exposed cervical dentin as a result of chemical (erosive foods and drinks), thermal (hot and cold), mechanical (brushing) or osmotic stimuli of opened dentin tubules. This is a common problem found in many adult populations with a prevalence ranging from 8 to $57 \%(1,2)$.

Unfortunately, little information is currently available on the effects of acidic substances on dentin permeability and dentin hypersensitivity. It has been demonstrated that acidic substances are able to remove the smear layer and open the dentin tubules. It is likely that acidic drinks are responsible for dentin hypersensitivity and for alterations in dentin permeability. A close relationship among open dentin tubules, dentin permeability and dentin hypersensitivity has been clearly demonstrated. The higher permeability the greater the clinical hypersensitivity $(3,4)$.

As a second problem, other procedures such as toothbrushing and dentifrice application may modify dentin morphology and smear layer. However, acidic drinks applied immediately before brushing procedures may increase the risk of smear layer removal and alterations of dentin structure. Brushing with abrasive dentifrice for either sensitive or non-sensitive teeth causes occlusion of many or most dentin tubules, but with remarkable abrasion of dentin (5). Kuroiwa et al. (6) evaluated the brushing effects on the dentin exposed

Correspondence: Prof. Dr José Eduardo Cezar Sampaio, Departamento de Diagnóstico Bucal e Cirurgia, UNESP, Faculdade de Odontologia de Araraquara, Rua Humaitá, 1680, 14801-903 Araraquara, SP, Brasil. Fone/Fax: +55-16-3301-6369/3301-6374. e-mail: jsampaio@foar.unesp.br 
to the oral cavity for 8 weeks, and revealed that brushing with an abrasive dentifrice for gingivitis did not occlude the dentin tubules, but caused erosion of the superficial layers of the exposed dentin. Under brushing without dentifrice, on the other hand, they found only little dentin abrasion and all dentin tubules were entirely occluded with the organic-mineral membrane or pellicle.

The aim of this in vitro study was to quantify alterations in root dentin permeability after exposure to different acid beverages, and brushing effect (sonic brush) with and without dentifrice after acid application.

\section{MATERIAL AND METHODS}

\section{Specimens}

This study was approved by the Research Ethics Committee of Araraquara Dental School, São Paulo State University, Brazil (Protocol number 52/04).

Twenty-five human third molars extracted for surgical reasons from young patients (mean age $=22$ years) were used. The crowns were sectioned and only the root segment was used ( $\mathrm{n}=5$ for each group). The pulp tissue was removed with a Hedström file. The root segment was glued with cyanoacrylate adhesive to an acrylic resin apparatus, which permits the perfusion of the connected pressure fluid-filled system (Fig. 1).

\section{Dentin Permeability Evaluation}

For dentin permeability evaluation, the root segment was connected to a fluid-filled system working at a pressure of 10 psi. A microcapillary tube with $25 \mu \mathrm{L}$ diameter was positioned between the pressure reservoir and the root segment (Fig. 1). The length of the microcapillary tube was $65 \mathrm{~mm}$. The length and

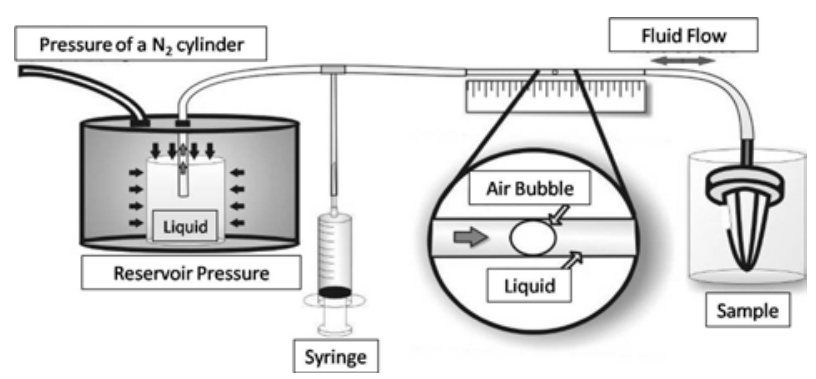

Figure 1. Schematic drawing showing how specimens were created and how fluid permeability was measured. diameter of the microcapillary tube permitted calculation of the hydraulic conductance $(7,8)$.

After preparation, the specimens were randomly assigned to 5 groups $(n=5)$ according to the acidic beverage in which they were immersed. The $\mathrm{pH}$ of the beverages was measured at room temperature before each test: orange juice: 3.35 , cola-drink: 2.45 , vinegar: 2.47, white wine: 3.35 and lemon juice: 2.10 .

Each specimen was connected to the hydraulic pressure apparatus to measure the dentin permeability of root dentin after the following sequential stages: Stage 1: Topical application of $37 \%$ phosphoric acid on dentin surface for $30 \mathrm{~s}$ to obtain the maximum permeability $(100 \%)$ followed by rinsing with distilled water; Stage 2: Root planing with Gracey 5-6 curette (50 strokes - Millenium; Golgran Ind. Com. de Instrumentos Odontológicos Ltda, São Paulo, SP, Brazil) to create new smear layer, rinsed with distilled water; Stage 3: specimens were immersed in $5 \mathrm{~mL}$ of acid beverage for 5 min (Orange juice, cola drink, vinegar, white wine and lemon juice), rinsed with distilled water; Stage 4: Toothbrushing with sonic toothbrush and distilled water for $3 \mathrm{~min}$, rinsing with distilled water; Stage 5: Toothbrushing with sonic toothbrush and $0.5 \mathrm{~g}$ of dentifrice (Colgate Sensitive; Colgate-Palmolive Ind. e Com. Ltda., São Paulo, SP, Brazil) for 3 min, and rinsing with distilled water.

The hydraulic conductance was expressed as a percentage of the maximum value for each specimen. Therefore, each specimen was taken as its own control.

\section{Statistical Analysis}

The linear displacement of the air blister in the microcapillary tube was measured, according to the time unit, in each stage. The most prevalent value was used to calculate the fluid flow through dentin. The flow obtained after stage I was considered the maximum permeability $(100 \%)$, and the other values were expressed in percentages referring to that maximum.

Statistical analysis of data was performed across these values, using the GraphPad Prism 5.0 statistical software package (GraphPad Software Inc., La Jolla, CA, USA). Means and standard deviations of permeability values were calculated and compared. Kruskal-Wallis test and Dunn's post test were applied to evaluate the differences in permeability after each stage into the same group and to evaluate the different stages among different groups. Significance level was set at 5\%. 


\section{RESULTS}

Dentin treated with $37 \%$ phosphoric acid served as the control group, whose permeability corresponded to $100 \%$, as reported elsewhere (7). Distribution of dentin permeability data are shown on Table 1 .

Table 2 shows the comparison of the experimental stages within the same material and among the materials.

\section{DISCUSSION}

The identification of etiologic factors that render dentin exposed and tubules open is an important factor for preventing and treating dentin hypersensitivity. Acidic

Table 1. Mean values (\%) and standard deviations of dentin permeability for all groups and stages.

\begin{tabular}{|c|c|c|}
\hline Group & Stage & Mean (SD) \\
\hline \multirow{4}{*}{ Orange juice } & 2 & $49.00(14.57)$ \\
\hline & 3 & $148.33(29.17)$ \\
\hline & 4 & $115.00(27.14)$ \\
\hline & 5 & $87.16(28.47)$ \\
\hline \multirow{4}{*}{ Cola drink } & 2 & $50.66(25.88)$ \\
\hline & 3 & $139.83(39.04)$ \\
\hline & 4 & $91.16(25.19)$ \\
\hline & 5 & $62.83(28.55)$ \\
\hline \multirow{4}{*}{ Vinegar } & 2 & $28.83(9.47)$ \\
\hline & 3 & $147.16(49.42)$ \\
\hline & 4 & $95.16(42.13)$ \\
\hline & 5 & $74.16(21.25)$ \\
\hline \multirow{4}{*}{ White wine } & 2 & $62.00(10.13)$ \\
\hline & 3 & $132.00(34.62)$ \\
\hline & 4 & $103.83(48.89)$ \\
\hline & 5 & $79.33(45.00)$ \\
\hline \multirow{4}{*}{ Lemon } & 2 & $52.33(13.55)$ \\
\hline & 3 & $187.83(85.94)$ \\
\hline & 4 & $147.83(79.57)$ \\
\hline & 5 & $118.00(58.74)$ \\
\hline
\end{tabular}

beverages contain citric acid, phosphoric acid, malic acid and others that are commonly used in operative dentistry to etch both enamel and dentin, and so frequent ingestion of these beverages can lead to loss of dental structure or smear layer removal, followed by dentin hypersensitivity $(4,9)$. Pashley (8) observed that the teeth are not usually hypersensitive immediately after root scaling because the dentin tubules remain occluded by the smear layer created by instrumentation. However, toothbrushing and acid substances could promote loss of the smear layer, which allows fluid movement in the dentin tubules in response to stimuli.

In the present study, the smear layer was created by hand instrumentation with curettes for subsequent removal by the acidic substances. The presence of smear layer represents $86 \%$ of total resistance in dentin permeability and pulp tissue removal does not promote statistically significant difference in permeability (10). Thus, in the present study pulp tissue removal did not interfere with the results.

Hydraulic conductance offers proper analysis of dentin permeability qualitatively and quantitatively (11). Dentin tubule occlusion can occur along its extension, and this method reveals the presence of particles inside the tubules.

The studies on dentin permeability are important because the mechanism of fluid flow is related to the pain. The evaluation of dentin permeability is performed by calculating the hydraulic conductance by method of fluid filtration (12). This method is the measurement of a fluid volume forced through a dentin barrier on a determined hydrostatic pressure for unit of area, time and/or pressure. The movement of an air bubble introduced by a syringe into the system indicates the amount of fluid that passes through the exposed dentin (12), allowing the measure to be repeated in the same specimen.

A constant hydrostatic pressure of 10 psi was used. The fluid used was distilled water, which presents a good capacity to permeate dentin. This fluid has previously been used by our research group (13).

The hydraulic conductance varied according to the degree of dentin tubule occlusion, the area of surface and the dentin thickness, and this parameter varied with the experimental conditions. The tooth is unique regarding the morphology of dentin tubules, and thus the use of the same teeth as control is necessary $(4,11,13)$. In this study and in previous ones, after acid etching of the teeth, the gauging of the dentin permeability was performed and this value was considered $100 \%$. Thus, 
the changes in permeability in this experiment were considered a percentage of Stage 1, using the Lp value as $100 \%$ flow permits evaluation of modifications in dentin permeability following the test treatments. Each specimen was its own control $(4,6,11,12)$.

This study showed that exposure to acidic beverages removed the smear layer surface and increased dentin permeability. This data demonstrated that the application of several acid beverages for a relatively short exposure of time is sufficient to remove the smear layer and to induce several alterations to the dentin surface. The specimens were kept immersed in acidic beverages for $5 \mathrm{~min}$ because this is the time necessary for the saliva to neutralize and/or remove the acid of the tooth surfaces (14). All the acidic beverages tested in this study increased the permeability after a single

Table 2. Comparison of the experimental stages within the same group and among the different groups.

\begin{tabular}{|c|c|c|c|c|c|c|c|c|c|c|c|c|c|c|c|c|c|c|c|c|c|c|c|c|c|}
\hline & & \multicolumn{5}{|c|}{ Orange juice } & \multicolumn{5}{|c|}{ Cola drink } & \multicolumn{4}{|c|}{ Vinegar } & \multicolumn{5}{|c|}{ White wine } & \multicolumn{5}{|c|}{ Lemon } \\
\hline & & $\mathrm{S} 1$ & $\mathrm{~S} 2$ & $\mathrm{~S} 3$ & S4 & S5 & $\mathrm{S} 1$ & $\mathrm{~S} 2$ & S3 & S4 & S5 & $\mathrm{S} 1$ & $\mathrm{~S} 2$ & S3 & S4 S5 & $\mathrm{S} 1$ & $\mathrm{~S} 2$ & S3 & S4 & S5 & $\mathrm{S} 1$ & $\mathrm{~S} 2$ & S3 & S4 & S5 \\
\hline \multirow{5}{*}{$\begin{array}{l}\text { Orange } \\
\text { juice }\end{array}$} & $\mathrm{S} 1$ & & & & & & & & & & & & & & & & & & & & & & & & \\
\hline & $\mathrm{S} 2$ & & & $\mathrm{c}$ & $\mathrm{a}$ & & & & $\mathrm{b}$ & & & & & $\mathrm{a}$ & & & & $\mathrm{b}$ & & & & & $\mathrm{c}$ & $\mathrm{a}$ & \\
\hline & S3 & & $\mathrm{c}$ & & & $\mathrm{a}$ & & $\mathrm{b}$ & & & $\mathrm{a}$ & & $\mathrm{c}$ & & & & $\mathrm{b}$ & & & $\mathrm{a}$ & & $\mathrm{b}$ & & & \\
\hline & S4 & & $\mathrm{a}$ & & & & & & & & & & $\mathrm{b}$ & & & & & & & & & & & & \\
\hline & S5 & & & a & & & & & $\mathrm{a}$ & & & & & & & & & & & & & & & & \\
\hline \multirow{5}{*}{$\begin{array}{l}\text { Cola } \\
\text { drink }\end{array}$} & S1 & & & & & & & & & & & & $\mathrm{a}$ & & & & & & & & & & & & \\
\hline & $\mathrm{S} 2$ & & & $\mathrm{~b}$ & & & & & $\mathrm{~b}$ & & & & & $\mathrm{a}$ & & & & $\mathrm{b}$ & & & & & $\mathrm{b}$ & & \\
\hline & S3 & & $\mathrm{b}$ & & & $\mathrm{a}$ & & $\mathrm{b}$ & & & $\mathrm{a}$ & & $\mathrm{c}$ & & & & $\mathrm{a}$ & & & & & $\mathrm{a}$ & & & \\
\hline & S4 & & & & & & & & & & & & & & & & & & & & & & & & \\
\hline & S5 & & & $\mathrm{a}$ & & & & & $\mathrm{a}$ & & & & & & & & & a & & & & & $\mathrm{b}$ & & \\
\hline \multirow{5}{*}{ Vinegar } & S1 & & & & & & & & & & & & b & & & & & & & & & & & & \\
\hline & $\mathrm{S} 2$ & & & $\mathrm{c}$ & $\mathrm{b}$ & & a & & $\mathrm{c}$ & & & $\mathrm{b}$ & & $\mathrm{c}$ & & $\mathrm{a}$ & & $\mathrm{c}$ & & & & & $\mathrm{c}$ & $\mathrm{b}$ & $\mathrm{a}$ \\
\hline & S3 & & $\mathrm{a}$ & & & & & $\mathrm{a}$ & & & & & $\mathrm{c}$ & & & & & & & & & & & & \\
\hline & S4 & & & & & & & & & & & & & & & & & & & & & & & & \\
\hline & S5 & & & & & & & & & & & & & & & & & & & & & & & & \\
\hline \multirow{5}{*}{$\begin{array}{l}\text { White } \\
\text { wine }\end{array}$} & S1 & & & & & & & & & & & & $\mathrm{a}$ & & & & & & & & & & & & \\
\hline & $\mathrm{S} 2$ & & & $\mathrm{~b}$ & & & & & $\mathrm{a}$ & & & & & & & & & $\mathrm{b}$ & & & & & $\mathrm{b}$ & & \\
\hline & S3 & & $\mathrm{b}$ & & & & & $\mathrm{b}$ & & & $\mathrm{a}$ & & $\mathrm{c}$ & & & & $\mathrm{b}$ & & & $\mathrm{a}$ & & $\mathrm{b}$ & & & \\
\hline & S4 & & & & & & & & & & & & & & & & & & & & & & & & \\
\hline & S5 & & & $\mathrm{a}$ & & & & & & & & & & & & & & $\mathrm{a}$ & & & & & $\mathrm{a}$ & & \\
\hline \multirow{5}{*}{ Lemon } & S1 & & & & & & & & & & & & & & & & & & & & & & & & \\
\hline & S2 & & & $\mathrm{b}$ & & & & & $\mathrm{a}$ & & & & & & & & & $\mathrm{b}$ & & & & & $\mathrm{c}$ & $\mathrm{a}$ & \\
\hline & S3 & & c & & & & & $\mathrm{b}$ & & & $\mathrm{b}$ & & $\mathrm{c}$ & & & & $\mathrm{b}$ & & & a & & $\mathrm{c}$ & & & \\
\hline & $\mathrm{S} 4$ & & a & & & & & & & & & & $\mathrm{b}$ & & & & & & & & & $\mathrm{a}$ & & & \\
\hline & S5 & & & & & & & & & & & & $\mathrm{a}$ & & & & & & & & & & & & \\
\hline
\end{tabular}

Statistical analysis by Kruskal-Wallis and Dunn's post-test - (a) $=p<0.05$, (b) $=p<0.01$ and (c) $=p<0.001$. 
5-min application and may perfectly simulate the typical oral assumption that occurs several times a day. These results were also found in other studies $(6,13)$.

The acid beverages that caused the highest increase in dentin permeability were lemon juice (187.83\%), orange juice (148.33\%), vinegar (147.16\%), cola drink $(139.83 \%)$ and white wine $(184 \%)$. The $\mathrm{pH}$ of lemon juice (2.1) was the smallest, followed by coca-cola (2.45), vinegar (2.47), orange juice (3.35) and white wine (3.35).

The $\mathrm{pH}$ is an important factor that may influence in dentin erosion. The $\mathrm{pH}$ is easily obtained, and it is the most used index to indicate the acidic of a product. However, there are various other features of beverages that cause an increase in teeth abrasion, such as buffering capacity and the kind of acid present in the beverages $(15,16)$. Although $\mathrm{pH}$ is the most used method, it is not the most accurate in the determination of erosion potential because it only indicates the initial acidity. The titratable or total acidity is a better method to indicate this potential, because it shows a total concentration of hydrogen ions (15). The acidic beverages used in this study were employed in normal concentration, in other words, they were not diluted. The dilution can decrease the titratable or total acidity, resulting that the more the solutions are diluted, the least are their erosive potential.

The next stage was toothbrushing of the specimens previously exposed to the acidic beverages. After toothbrushing, cola drink (139.83\% to $91.16 \%)$ and white wine (132\% to $103.83 \%$ ) caused a significant decrease in dentin permeability. Orange juice (148.33\% to $115 \%)$, vinegar $(147.16 \%$ to $95.16 \%$ ) and lemon juice $(187.83 \%$ to $147.83 \%)$ did not diminish dentin permeability significantly. Zandim et al. (13), after application of different orange juices, observed that navel orange, valencia orange and Mandarin orange were more effective in removal of smear layer and exposure of dentin tubules in comparison with lime orange and lime, and the authors showed that toothbrushing without dentifrice tends to increase smear layer removal after orange juice application. This difference probably happened due to the acid features of each beverage. Although the orange juice showed larger $\mathrm{pH}$, it is the beverage that presents greater erosive capacity as shown in a study by Prati et al. (6). Thus, the Canadian Advisory Board on Dentin Hypersensitivity advises the patients with risk of erosion or abrasion to brush their teeth before meals and avoid ingestion of acidic beverages.

The type of acid can also influence in the erosion potential. The citric acid present in orange juice and lemon juice is one of the most erosive acids due to their chelating capacity, which is responsible for calcium seize from saliva and teeth. Lemon juice presents the greatest citric acid concentration (5-7\%) among the tested beverages (16).

The acid that is found in wine is a mix of the fruit acids themselves (maleic, tartaric, citric, oxalic acid) and acids originated from fermentation, such as succinic, latic, acetic and piruvic acid. The different proportions among these acids can explain the variation of $\mathrm{pH}$ among different wines. The most acid wine is white wine (16).

Vinegar is composed by acetic acid (about 5\% in concentration) (16). Zandim et al. (17) evaluated the action of vinegars on exposure of dentin tubules, and used two methods for application. Topical application to simulate the contact of exposed cervical dentin with acid foods and drinks, and the active application by friction to verify if toothbrushing tends to accentuate the erosive action of dietary acids. The authors observed that vinegars were able to remove smear layer and open dentin tubules; alcohol, apple and rice vinegars caused the greatest effects.

The phosphoric acid is found mainly in soft drinks ("colas"). These soft drinks also have in their composition carbonic acid and show phosphate in excess, which damages the metabolism of calcium, favoring osteoporosis (16). The cola drink presented lower acid concentration than the other studied beverages, which can be responsible for the lower erosive potential observed in the present study. The cola drink was the acidic beverage that produced the smallest dentin permeability after exposure of specimens for $5 \min (16)$.

In stage 5, all specimens were sonic brushed with dentifrice for $3 \mathrm{~min}$. A large number of studies showed that toothbrushing with dentifrice was able to occlude dentin tubules or decrease dentin permeability, due to the presence of desensitizing agents or abrasives particles in the tubules $(5,18,19)$. Other in vitro studies that used toothbrushing with dentifrice showed dentin abrasion or erosion to a variable degree and tubule opening. In the present study, toothbrushing with dentifrices decreased dentin permeability, though without significant differences. An explanation for this finding may be the application of acidic beverages before toothbrushing, without intervals between the exposure to the acid diet and the toothbrushing. According to West et al. (18), the same specimens were etched before toothbrushing with different dentifrices. The results showed that the dentifrices were able of obliterate dentin tubules. 
In another study (20), specimens exposed to orange juice (5 $\mathrm{min}$ ) after toothbrushing with dentifrice had almost all or all deposits removed, differing from the control group, which had totally obliterated tubules. Thus, it was concluded that citric acid presented greater erosive potential because orange juice very rapidly removed the surface deposits of dentifrices (20).

Caution must be exercised in extrapolating the present in vitro results to the in vivo condition, although optimal conditions were established to conduct this study and minimize biases. Our findings showed that an acid diet can remove smear layer and open dentin tubules, thus increasing dentin permeability. Subsequent brushing with sonic toothbrush and distilled water or dentifrice promoted a small decrease of dentin permeability.

Considering the methodology employed in the study, and based on its limitations, it may be concluded that acidic beverages are able of causing dentin tubule exposure by smear layer removal. Toothbrushing with dentifrice or not can decrease dentin permeability. However, this decrease is small when toothbrushing is performed soon after exposure to an acid diet.

\section{RESUMO}

Este estudo quantificou a alteração na permeabilidade da dentina radicular submetida a diferentes dietas ácidas. Vinte e cinco terceiros molares foram seccionados abaixo da junção cementoesmalte, a raiz seccionada foi selecionada, e a polpa removida. A seguir, as amostras foram conectadas a um aparato de pressão hidráulica para medir a permeabilidade da dentina radicular de acordo com os seguintes passos: I) tratamento com ácido fosfórico por $30 \mathrm{~s}$ (permeabilidade máxima), II) aplainamento radicular para criar nova smear layer, III) exposição a diferentes substâncias ácidas por 5 min (suco de laranja, coca-cola, vinagre, vinho branco e suco de limão), IV) escovação com escova sônica por $3 \mathrm{~min}, \mathrm{~V}$ ) escovação com escova sonica mais dentifrício, por 3 min. Os dados foram convertidos em porcentagem em relação ao passo I (100\%) e cada amostra foi seu próprio controle. Os resultados mostraram que todas as substâncias ácidas aumentaram significantemente a permeabilidade dentinária após raspagem. Escovação após a exposição a substâncias ácidas diminuiu a permeabilidade e a associação com dentifrício aumentou a redução na permeabilidade dentinária; essa redução adicional não foi observada somente nas amostras tratadas com coca-cola. Com isso, pode-se concluir que todas as substâncias ácidas testadas aumentaram a permeabilidade dentinária, e a escovação com ou sem dentifrício pode diminuir a permeabilidade dentinária radicular após a exposição da dentina a dieta ácida.

\section{REFERENCES}

1. Ritter AV, de L Dias W, Miguez P, Caplan DJ, Swift EJ Jr. Treating cervical dentin hypersensitivity with fluoride varnish: a randomized clinical study. J Am Dent Assoc 2006;137:1013-1020.

2. Ahmed TR, Mordan NJ, Gilthorpe MS, Gillam DG. In vitro quantification of changes in human dentine tubule parameters using SEM and digital analysis. J Oral Rehabil 2005;32:589-597.

3. Erdemir U, Yildiz E, Kilic I, Yucel T, Ozel S. The efficacy of three desensitizing agents used to treat dentin hypersensitivity. J Am Dent Assoc 2010;141:285-296.

4. Sauro S, Watson TF, Thompson I. Dentine desensitization induced by prophylactic and air-polishing procedures: An in vitro dentine permeability and confocal microscopy study. J Dent 2010;38:411-422.

5. Petrou I, Heu R, Stranick M, Lavender S, Zaidel L, Cummins D, et al.. A Breakthrough therapy for dentin hypersensitivity: how dental products containing $8 \%$ arginine and calcium carbonate work to deliver effective relief of sensitive teeth. J Clin Dent 2009;20:23-31.

6. Kuroiwa M, Kodaka T, Kuroiwa M, Abe M. Dentin hypersensitivity. Occlusion of dentin tubules by brushing with and without an abrasive dentifrice. J Periodontol 1994;65:291-296.

7. Prati C, Montebugnoli I, Suppa P, Valdrè G, Mongiorgi R. Permeability and morphology of dentin after erosion induced by acidic drinks. J Periodontol 2003;74:428-436.

8. Pashley DH. Dentin permeability and dentin sensitivity. Proc Fin Dent Soc 1992;88:31-37.

9. Ayad F, Ayad N, Zhang YP, DeVizio W, Cummins D, Mateo LR. Comparing the efficacy in reducing dentin hypersensitivity of a new toothpaste containing $8.0 \%$ arginine, calcium carbonate, and 1450 ppm fluoride to a commercial sensitive toothpaste containing $2 \%$ potassium ion: An eight-week clinical study on Canadian adults. J Clin Dent 2009(Spec Iss):10-19.

10. Pashley DH, Kepler EE, Williams EC, Okabe A. The effects of acid etching on the in vivo permeability of dentine in the dog. Arch Oral Biol 1983;28:555-559.

11. Zandim DL, Leite FRM, Sampaio JEC. In vitro evaluation of the effect of dietary acids and toothbrushing on human root dentin permeability. Quintessence Int 2010;41:257-263.

12. Pashley DH, Livingston MJ, Reeder OW, Horner J. Effects of the degree of tubule occlusion on the permeability of human dentine in vitro. Arch Oral Biol 1978;23:1127-1133.

13. Zandim DL, Corrêa FO, Rossa Júnior C, Sampaio JE. In vitro evaluation of the effect of natural orange juices on dentin morphology. Braz Oral Res 2008;22:176-183.

14. Amaechi BT, Higham SM. Eroded enamel lesion remineralization by saliva as a possible factor in the site-specificity of human dental erosion. Arch Oral Biol 2001;46:697-703.

15. Cairns AM, Watson M, Creanor SL, Foye RH. The pH and titratable acidity of a range of diluting drinks and their potential effect on dental erosion. J Dent 2002;30:313-317.

16. Hannig C, Hamkens A, Becker K, Attin R, Attin T. Erosive effects of different acids on bovine enamel: release of calcium and phosphate in vitro. Arch Oral Biol 2005;50:541-552.

17. Zandim DL, Corrêa FOB, Sampaio JEC, Rossa Jr C. The influence of vinegars on exposure of dentin tubules: a SEM evaluation. Braz Oral Res 2004;18:63-68.

18. West NX, Hughes JA, Addy M. Dentine hypersensitivity: the effects of brushing toothpaste on etched and unetched dentine in vitro. J Oral Rehabil 2002;29:167-174.

19. Wang Z, Sa Y, Sauro S, Chen H, Xing W, Ma X, et al.. Effect of desensitizing toothpastes on dentin tubules occlusion: a dentine permeability measurement and SEM in vitro study. J Dent 2010;38:400-410.

20. Absi EG, Addy M, Adams D. Dentine hypersensitivity: uptake of toothpastes onto dentine and effects of brushing, washing and dietary acid - SEM in vitro study. J Oral Rehabil 1995;22:175-182. 